\title{
The Multihabitat Approach of USEPA's Rapid Bioassessment Protocols: Benthic Macroinvertebrates
}

\author{
Michael T. Barbour ${ }^{1, *}$, James B. Stribling ${ }^{1}$, and Piet F.M. Verdonschot ${ }^{2}$ \\ 1 Center for Ecological Sciences. Tetra Tech, Inc. 10045 Red Run Blvd., Suite 110. Owings Mills, MD 21117- \\ 6102. USA \\ 2 Alterra, Freshwater Ecosystems. 6700 AA Wageningen. The Netherlands. \\ * Corresponding author: Michael.Barbour@tetratech.com
}

\begin{abstract}
The Multihabitat Approach of USEPA's Rapid Bioassessment Protocols: Benthic Macroinvertebrates

The multihabitat approach to sampling for bioassessment is not a new concept, but has been described in detail in the USEPA Rapid Bioassessment Protocols (Barbour et al., 1999) and the AQEM project of the European Union (Hering et al., 2004). Although there are variations on this technique, the basic approach is to sample the major aquatic habitats in proportion to each representation in the stream reach. Both fish and benthic macroinvertebrates are sampled in this manner. The primary advantage of the multihabitat approach is to sample representative stream habitats that will address habitat altered systems and provide an indication of impairment from both chemical and non-chemical stressors. This technique has been shown to collect representative samples of the stream reach and to be highly precise among and within sampling crews. Four questions are addressed in this paper: (1) What are the strengths and limitations of the method for low-gradient streams; (2) What are the performance characteristics (i.e., accuracy, precision, sensitivity) of the method; (3) What is the relative ability of the method to distinguish natural variability (i.e., temporal, spatial) from human disturbance; (4) How would the method be implemented for low-gradient streams.
\end{abstract}

Key words: Multihabitat sampling, benthic macroinvertebrates, rapid bioassessment, precision, representativeness, Lowgradient streams, AQEM, Environmental monitoring, Ecological condition.

\section{RESUMEN}

\section{La aproximación multihábitat de los protocolos de bioevaluación rápida de la USEPA: Macroinvertebrados bentónicos}

La aproximación mediante muestreo multihábitat para bioevaluaciones no es un nuevo concepto, pero ha sido descrito en detalle en los Protocolos de Bioevaluación Rápida de la USEPA (Barbour et al., 1999) y en el proyecto AQEM de la Unión Europea (Hering et al., 2004). Aunque hay variaciones en esta técnica, la aproximación básica es muestrear los hábitats acuáticos en proporción a cada representación en el tramo de río. Tanto los peces como los invertebrados bentónicos son muestreados de esta manera. La principal ventaja de la aproximación multihábitat es el muestreo de de los hábitats representativos del río que indicaran sistemas con hábitats alterados y proporcionaran una indicación de desajuste entre factores de stress químicos y no químicos. Esta técnica ha mostrado que permite recolectar muestras representativas del tramo de río y ser altamente precisa tanto entre, como dentro campañas de muestreo. En este trabajo se abordan cuatro preguntas: (1) Cuales son los punto fuerte y las limitaciones del método para ríos de poco gradiente; (2) Cuales son las características representativas (p.e. exactitud, precisión, sensitividad) del método; (3) Cual es la habilidad relativa del método para diferenciar la variabilidad natural (p. e. temporal, espacial) de las perturbaciones humanas; (4) Como se podría implementar el método para ríos de poco gradiente.

Palabras clave: Muestreo multihábitat, macroinvertebrados bentónicos, bioevaluación rápida, precisión, representatividad, ríos de poco gradiente, AQEM, gestión ambiental, estado ecológico. 


\section{INTRODUCTION}

Traditional sampling procedures for benthic macroinvertebrates in lotic systems have targeted a single habitat type to reduce variability due to substrate differences (Rosenberg \& Resh, 1993; Loeb \& Spacie, 1994; Lenat \& Barbour, 1994). Numerous studies have been conducted to demonstrate the influence of substrate and other habitat types on the population dynamics of aquatic insects and other macroinvertebrates (e.g., Minshall, 1984), and have mostly focused on larger particle sizes (usually cobble and coarse gravel), which constitute the riffles and runs of flowing waters. Riffles are among the most productive habitat types in lotic systems, due largely to the turbulence they produce (and thus, higher levels of dissolved oxygen) and their capacity to capture and retain organic particulates. It is recognized, however, that not all streams have riffles, due either to natural geomorphic and topographic characteristics, or, as a result of accelerated rates of stream bottom erosion or fine sediment deposition. Low gradient plains regions (coastal or otherwise) tend to be dominated by sediment particle sizes ranging from medium and small gravel down to sand, silt, and clay.

In addition, a long history of stream sampling exists throughout the country and around the world where the focus of the studies has been on species (or taxa) inventories and distributions. The resurgence of bioassessment in the USA has provided the impetus for development of innovative strategies to integrate biological information into agency monitoring programs (Davis and Simon, 1995; Barbour, 1997). Part of the strategy has entailed reconsideration of the purpose of the biological sample, i. e., of what it is intended to be representative? Since analysis of the sample leads to assessment of an entire reach, not just a single habitat (e. g., a riffle), an approach yielding sample data representing the entire reach would be more appropriate. A multihabitat approach distributed over the entire reach, and that leads to sampling a portion of all habitat types present in the reach, is intended to improve sample representativeness. The proportionallydistributed, multihabitat sample reflects the biota that a stream (even a degraded one) has the capacity to support. One exposed riffle in the middle of an otherwise eroding, sand-clogged channel is NOT representative of the stream for an assessment of ecological condition.

Use of multiple habitat sampling in biological assessments is not new. North Carolina Department of Environmental Management (DEM) has long used the technique of sampling a variety of stream habitats to assess condition (Lenat, 1988 and 1990; Lenat and Barbour, 1994). While the sampling emphasis of North Carolina DEM was on the riffle habitat, supplemental sampling was also done in the shorezone vegetation, woody debris, and sand habitats (which was mostly for midge larvae). Over the past decade, other monitoring and assessment programs in the United States have developed multihabitat sampling techniques, e.g., the eastern states in the Mid-Atlantic Coastal Plains of the US (MACS 1996; Maxted et al., 2000), Florida Department of Environmental Protection (DEP) (Florida DEP, 1996; Barbour et al., 1996), Massachusetts DEP (Massachusetts DEP, 1995; and Alaska Department of Environmental Conservation -DEC-) (Major et al., 1998; Major and Barbour, 2001). The development of these state methods provided the basis for the multihabitat procedures described in the second edition of the RBPs (Barbour et al., 1999; Table 1).

Also in Europe, multihabitat sampling for monitoring and assessment purpose was used for nearly three decades (e.g., De Lange and De Ruiter, 1977; Woodiwiss, 1978; Furse et al., 1981). An extensive overview of samplers and efficiencies and comparisons of techniques was given by Elliott and Tullett (1983). The use of species based assessment techniques such as the Saprobien System (Sladecek, 1978) as well as community based approaches like RIVPACS and EKOO (Wright et al., 2000) were based on multihabitat sampling. The differences of the European approach from that of the RBPs are (i) the inclusion of rare habitats and (ii) the non-proportional allocation of sampled area to habitats present.

The purpose of this paper is to describe the multihabitat stream sampling approach for ben- 
thic macroinvertebrates (Barbour et al., 1999), that uses proportional allocation of sampling effort across all major habitat types present in the target reach. The application of this approach to low-gradient streams is discussed. We ask four questions: (1) What are the strengths and limi- tations of the method for low-gradient streams; (2) What are the performance characteristics (i.e., accuracy, precision, sensitivity) of the method; (3) What is the relative ability of the method to distinguish natural variability (i.e., temporal, spatial) from human disturbance; (4) How would

Table 1. Summary of the primary technical elements of USEPA's Multihabitat Approach. Resumen de los elementos técnicos primaries de la Aproximación Multihábitat USEPA.

\begin{tabular}{|c|c|}
\hline Habitat Selection & - Reach determined as 100 meters in length. Length could be determined by some multiple of width. \\
\hline Sampling Gear & $\begin{array}{l}\text { - Rectangular net } 50 \mathrm{~cm} \text { wide or D-frame net } 30 \mathrm{~cm} \text { wide. } \\
\text { - } 500 \mu \mathrm{m} \text { mesh. }\end{array}$ \\
\hline Sampling Method & $\begin{array}{l}\text { - Sample units collected at multiple habitats with effort in proportion to representation in reach. } \\
\text { - Habitats targeted are cobble (hard substrate), snags, vegetated shorezone, submerged aquatics, sand } \\
\text { or other fine sediment. } \\
\text { - } 20 \text { jabs/kicks are collected among the habitats in the reach. } \\
\text { - Composited as a single sample representing the reach. }\end{array}$ \\
\hline Area Sampled & $\begin{array}{l}\text { - Area per sample unit is } \sim 0.5 \mathrm{~m}^{2} \\
\text { - Area per composite sample is variable depending on the gear type and level of effort, but generally } \\
1.8 \text { to } 5.0 \mathrm{~m}^{2}\end{array}$ \\
\hline Replication & - $10 \%$ of sites replicated. \\
\hline Replication as QA/QC & $\begin{array}{l}\text { - Same season, different team revisits (2 sites). } \\
\text { - Next year revisits (10 sites). }\end{array}$ \\
\hline $\begin{array}{l}\text { Subsampling and } \\
\text { Enumeration }\end{array}$ & $\begin{array}{l}\text { - Random subsampling to } 300+/-20 \% \text { organism count/identification (could be } 200 \text { organisms as } \\
\text { target). } \\
\text { - Power Cost Efficiency (PCE) test done to determine organism target. }\end{array}$ \\
\hline Taxonomic Level & $\begin{array}{l}\text { - Genus or lowest taxon possible. } \\
\text { - Family level taxonomy used in some states. }\end{array}$ \\
\hline QA Procedures & $\begin{array}{l}\text { - Field: revisit by different team-same year (2 sites) and second year revisit on } 10 \text { sites. } \\
\text { - Vouchers and reference collection maintained. } \\
\text { - Lab: sorting checks } 10 \% \text {; ID checks } 10 \% \text {. }\end{array}$ \\
\hline Analysis/Metrics & $\begin{array}{l}\text { - Metrics calibrated for region or based on classification within states. } \\
\text { - Core metrics aggregated to an index for assessment, but analyzed separately to aid in diagnostics. } \\
\text { - RIVPACS used in certain cases. }\end{array}$ \\
\hline Habitat Assessment & $\begin{array}{l}\text { - Visual-based habitat assessment as per Barbour et al. } 1999 . \\
\text { - Wolman Pebble Count conducted to supplement interpretation of bed sediments. }\end{array}$ \\
\hline $\begin{array}{l}\text { Data Availability and } \\
\text { Mode of Storage }\end{array}$ & $\begin{array}{l}\text { - Ecological Data Application System (EDAS) used by numerous states. } \\
\text { - Link to STORET established for legacy ecological data upload and download. }\end{array}$ \\
\hline $\begin{array}{l}\text { Written Protocols } \\
\text { Availability }\end{array}$ & - Barbour et al. 1999. \\
\hline Comments & $\begin{array}{l}\text { - The proportional allocation method for the multihabitat method was tested and developed initially } \\
\text { for Alaska DEC and Massachusetts DEP, and based on similar methods being used for streams in } \\
\text { the mid-Atlantic coastal region and by Florida DEP. }\end{array}$ \\
\hline $\begin{array}{l}\text { Purpose for Monitoring } \\
\text { (in the USA) }\end{array}$ & $\begin{array}{l}\text { - Support State (or other agency) Surface Water Assessment and Monitoring Programs (SWAMP). } \\
\text { - Assess the biological condition of surface waters. } \\
\text { - Use in Aquatic Life Use determinations, TMDLs based on biological impairment, BMP effective- } \\
\text { ness monitoring. } \\
\text { - Diagnose causes of impairment. }\end{array}$ \\
\hline
\end{tabular}


the method be implemented for low-gradient streams.

\section{OVERVIEW OF METHODS}

The multihabitat approach of the USEPA RBPs advocates sampling the habitat types in proportion to their frequency of occurrence in the stream reach. For example, the substrate in a high-gradient stream in the Cascade Mountains in northwestern US is dominated by cobble and boulders, woody debris, and pockets of coarse particulate matter. If woody debris is removed, fauna associated with it are directly affected. Sampling the woody debris in reference streams, but not sampling in habitat-altered streams provides the basis for evaluating effects of physical habitat degradation. As another example, lowgradient streams of the Central Valley in California are dominated by soft, fine sediment, shorezone, submerged vegetation habitats, and are distinctive by an overwhelming absence of cobble substrate and woody debris. The USEPA multihabitat procedure was designed as a technique for sampling these types of streams, and to provide a sample representative of the benthic macroinvertebrates the stream has the capacity to support (Barbour et al., 1999; Maxted et al., 2000). The RPB method was adopted in the European project, translated as "the development and testing of an integrated assessment system for the ecological quality of streams and rivers throughout Europe using benthic macroinvertebrates" (AQEM) (Hering et al., 2004). In combining the approach of the RBP (Barbour et al., 1999) with that of the procedures of the Environment Agency (Environment Agency, 1999), the Austrian Guidelines "Saprobiology" (Moog et al., 1999) and ISO 7828 (1985), guidelines were formulated into a standard procedure for collecting and analysing macroinvertebrate samples within the AQEM project (AQEM consortium, 2002). Herein the philosophy of the RBP was kept as standard.

As described in the RBP document (Barbour et al., 1999) as well as in the AQEM procedure (Hering et al., 2004), benthic ma- croinvertebrates are collected systematically from all available instream habitat types (in approximate proportion to their frequency of occurrence in the reach). The RBP uses the techniques of kicking the substrate or sweeping with a standard aquatic collecting net. In the USA, a D-frame dip net (or rectangular net similar to that used by the USEPA Environmental Monitoring and Assessment Program [EMAP] and the US Geological Survey National Water Quality Assessment [NAWQA]) is employed (Table 1). In AQEM a pond-net is used. By kicking the substrate (in fast running streams) to dislodge the organisms into a stationary net or sweeping the net (in slow running streams) to capture loosely clinging organisms, this technique affords versatility in sampling the benthic macroinvertebrate assemblage from the various habitats.

A composite of several sample units (SU), usually 20 SUs, is taken from all major habitat types in the stream reach, resulting in sampling of approximately $1.25 \mathrm{~m}^{2}$ (Hering et al., 2004) to $3.1 \mathrm{~m}^{2}$ (Barbour et al., 1999); the habitat surface area depends upon the dimensions of the net and the SUs composited (Table 1). As an example, if the habitat in the sampling reach is estimated to be $50 \%$ snags or woody debris, 25 $\%$ cobble, and $25 \%$ vegetation, then half of the sampling effort (50\% or $10 \mathrm{SUs}$ ) should be taken in the woody debris habitat, and the other 10 SUs divided between the cobble and vegetation. An organism-based subsample (usually 200, 300, or 500 organisms) is sorted in the laboratory and identified to genus (Table 1).

Following are specific sampling techniques for different habitat types (taken from Barbour et al., 1999):

\section{Cobble (hard substrate)}

Cobble is associated with riffles and runs defined as the shallow part of the stream where water flows over completely or partially submerged pebble to boulder sized rocks to produce surface turbulence. This habitat type is not common in most low-gradient streams. Sample by holding 
Table 2. The strengths and limitations of EPA's multihabitat sampling method for benthic macroinvertebrates. Puntos fuertes $y$ limitaciones del método de muestreo multihábitat de la EPA para macroinvertebrados bentónicos.

\begin{tabular}{|c|c|}
\hline Strengths & Limitations \\
\hline Technical & Technical \\
\hline $\begin{array}{l}\text { - Emphasis is on available and appropriate habitats in } \\
\text { stream, based on natural expectations }\end{array}$ & $\begin{array}{l}\text { - Sampling woody debris or snags can be qualitative if not } \\
\text { done properly }\end{array}$ \\
\hline $\begin{array}{l}\text { Conducive to measuring effects from multiple stressors, } \\
\text { including both chemical and non-chemical }\end{array}$ & $\begin{array}{l}\text { - There is a tendency to over sample the most productive } \\
\text { habitats in a reach }\end{array}$ \\
\hline $\begin{array}{l}\text { Provides distinction between high-gradient and low- } \\
\text { gradient streams and reinforces classification of stream ty- } \\
\text { pes for assessment }\end{array}$ & $\begin{array}{l}\text { - The training of investigators to be consistent with deci- } \\
\text { sions regarding habitat representation in reach is difficult }\end{array}$ \\
\hline \multicolumn{2}{|l|}{$\begin{array}{l}\text { - Concept and procedure were developed specifically for } \\
\text { low-gradient streams, but are relevant to all types. }\end{array}$} \\
\hline Implementation & Implementation \\
\hline $\begin{array}{l}\text { The same technique is appropriate for all stream types, } \\
\text { making a single method applicable statewide }\end{array}$ & $\begin{array}{l}\text { - For statewide implementation, a cross-method compari- } \\
\text { son may be necessary to adjust historical data }\end{array}$ \\
\hline $\begin{array}{l}\text { - Once trained, multiple investigators can conduct sampling } \\
\text { in a standardized manner }\end{array}$ & $\begin{array}{l}\text { - Can add a dimension to diagnosing impairment between } \\
\text { chemical and non-chemical stressors }\end{array}$ \\
\hline \multicolumn{2}{|l|}{$\begin{array}{l}\text { - This technique is used by other states and endorsed by } \\
\text { EPA, providing documented support for its implementa- } \\
\text { tion }\end{array}$} \\
\hline $\begin{array}{l}\text { - Once the method and associated index is calibrated, the } \\
\text { technique is relatively cost-effective }\end{array}$ & \\
\hline
\end{tabular}

the bottom rim of the dip net against the substrate downstream of the riffle and perpendicular to the flow while disturbing the substrate just upstream of the net with feet and hands to dislodge organisms. Large substrate particles should be rubbed by hand to dislodge attached organisms. The same method is used in the AQEM approach.

\section{Snags (woody debris)}

Submerged woody debris is sampled by jabbing in medium-sized sticks and branches; each SU is an estimated 1-meter section. The snag habitat may be kicked first to help dislodge organisms, but do so only after placing net in water downstream of the snag. Accumulated woody material in pool areas can also be considered as snag habitat. Large materials (e.g., logs) are usually avoided since they are not generally productive. The same method is used in the AQEM approach.

\section{Aquatic macrophytes}

Aquatic plants that are rooted on the bottom of the stream are sampled by sweeping the net through the vegetation from the bottom to the surface of the water; in shallow water or shorezone areas, vegetation is sampled by bumping or pushing the net along the bottom in the rooted area. A single SU is defined as an estimated $1 \mathrm{~m}$ length $\times$ net width. Aquatic macrophytes are seasonal in their occurrence and thus, timing of sampling is critical. In the AQEM, the net is swept several times up and down through the submerged plant parts of emergent, floating and submersed vegetation.

\section{Vegetated Bank Margins}

When the lower portion of banks have roots, plants, and snags associated with them, they are sampled in a fashion similar to snags. If the banks are of unvegetated or soft soil, they are sampled by bumping the net along the substrate rather than dragging the net through soft substrates; this will reduce the amount of detritus (defined as sticks, leaves, and/or pieces of bark), an abundance of which will drastically increase laboratory processing effort. Bank habitat also can be kicked first to help dislodge organisms. In the AQEM, the 
net is swept several times up and down through the submersed bank vegetation as discussed with the submerged aquatic macrophytes.

\section{Sand (and other fine sediment)}

Usually the least productive macroinvertebrate habitat in streams, this habitat may be the most prevalent in some streams (particularly in lowgradient streams). Unvegetated or soft sediments are sampled by bumping or pushing the net in short, jerky movements along the surface of the substrate to penetrate only the upper centimeters of the substratum. Then sweep the net immediately above the disturbed area. Alternatively, kick area of soft sediment to dislodge sediment and organisms into the water column, and then sweep through the suspended cloud of sediment. The same method is used in the AQEM approach.

\section{RESULTS AND DISCUSSION}

\section{Question 1-What are the strengths and limi- tations of the multihabitat method for low- gradient streams?}

The strengths and limitations of EPA's multihabitat method are best explained in a table that addresses both the technical issues and program implementation aspects that are relevant to an agency's requirement to conduct monitoring and assessment of surface waters (Table 2). While these strengths and limitations are pertinent to the method, regardless of stream type, the focus of this paper is on the low-gradient streams that are common around the world, and have historically been difficult ecosystems to sample effectively.

\section{Question 2-What are the performance cha- racteristics (i.e., representativeness, precision, sensitivity) of the multihabitat method?}

Evaluating the representativeness and precision of the multihabitat, strict proportional method for sampling stream macroinvertebrates and assessing biological condition is dependent on several factors. Quantitative measures of precision and laboratory accuracy are calculated from combinations of metrics, which are themselves calculated from per-sample taxonomic results, which are directly affected by laboratory sorting and subsampling procedures (if used). The confidence with which accuracy and precision can be evaluated is strongly diminished if performance characteristics of sample processing (sorting, subsampling, and taxonomy) are unknown. Representativeness encompasses accuracy, but refers to a broader aspect of the sampling, which is to ensure a sample represents the reach or stream of interest in an assessment. Therefore, there must be routine and rigorous documentation of all potential error sources in each component of the biological assessment protocol. Below is presented a discussion of the performance characteristics for field sampling and multimetric biological indices for the multihabitat approach.

Representativeness of field sampling is assessed qualitatively, and is, in large part, contingent upon specific objectives of the method. The multihabitat proportional method is intended to produce a sample representative of biota the existing stream habitat is able to support. Properly applied, then, the method minimizes oversampling of rare habitats and undersampling of dominant habitats, thus minimizing bias (and improving accuracy). It also provides for sampling habitat types that are poor, unstable, or under-productive. If these habitats dominate the physical structure of a stream reach, the biota existing in them are indicative of those conditions. An example on representative presence of taxa in multihabitat sampling in space and time was published by Verdonschot (1990). Ten replicate samples were taken at the same time, for which a homogeneous stretch of the stream was divided into ten reaches each $10 \mathrm{~m}$ long. Each reach was sampled according to the standard procedure using a pond net. This study was repeated in four different months (Table 3). A total of 286 taxa were collected at the replicated site within the forty samples (i.e., 10 samples $\times 4$ months). September appears to be the best month to take a sample: in September, an average $64 \%$ of all taxa and $84 \%$ of the common taxa were collected (Table 3 ). 
Table 3. Percentage of taxa caught on average in a standard pond net sample in dependence of the sampling date. (a) Percentage of all the taxa collected at the replicated site; (b) Percentage of the taxa present in $90 \%$ of the samples collected at the replicated site; (c) Percentage of the taxa present in $75 \%$ of the samples collected at the replicated site. Tanto por ciento de capturas promedio en el muestreo de un estanque con red estándar y en función de la fecha de muestreo. (a) Tanto por ciento de todos los taxones recolectados en una estación con réplica. (b) Tanto por ciento de taxones presentes en un $90 \%$ de las muestras recogidas en las estaciones con réplica. (c) Tanto por ciento de los taxones pfresentes en un $75 \%$ de las nuestras recogidas en las estaciones replicadas.

\begin{tabular}{ccccc}
\hline Month & Date & $\begin{array}{c}\text { \% of all } \\
\text { taxa (a) }\end{array}$ & $\begin{array}{c}\text { \% of more } \\
\text { common } \\
\text { taxa (b) }\end{array}$ & $\begin{array}{c}\text { \% of common } \\
\text { taxa (c) }\end{array}$ \\
\hline December & $03 / 12 / 84$ & 54 & 61 & 68 \\
April & $15 / 04 / 85$ & 55 & 63 & 67 \\
July & $08 / 07 / 85$ & 51 & 65 & 68 \\
September & $16 / 09 / 85$ & 64 & 77 & 84 \\
\hline
\end{tabular}

Precision of field sampling is evaluated quantitatively through analysis of repeat sampling. A repeat sample is defined as one (or more) collected from 100-meter stream reach(es) adjacent to the primary reach. For a monitoring program, the frequency and location of the adjacent reaches can vary, but a rate of $10 \%$ repeated is often used; which primary sites are done can either be randomly selected, or selected when there is an adjacent reach that is similar to the primary (i. e., exhibits similarity in physical habitat quality, and no evidence of additional stressors or stressor sources). If repeat samples are collected by a single field team, the precision values are an estimate of method consistency (intra-team precision); if different teams collect them the values represent method repeatability (inter-team precision). The difference between the two samples is calculated by relative percent difference $(R P D)$ using individual metric values and the final index score. As an example -using data from Mississippi Department of Environmental Quality (DEQ)- most individual metrics had median RPD values of $<30$ for both kinds of repeat samples; the overall index scores from repeat samples had a median RPD of 10.5 (Mississippi DEQ 2003). It should be noted that RPD results can be biased if the metric value from one of the two samples is zero (0). It is, thus, not always

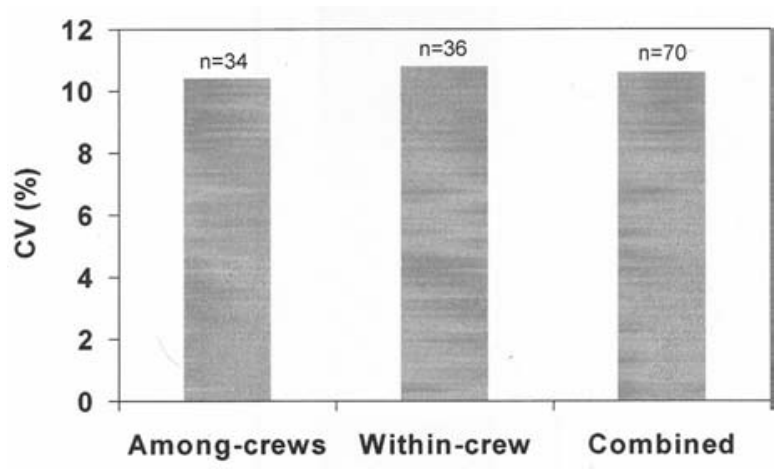

Figure 1. Coefficient of variability (CV) for benthic macroinvertebrate multihabitat samples collected in the state of Mississippi, USA. The values for "n" represent the number of sample pairs used in calculating the CV. Coeficiente de variabilidad (CV) para muestreos multihábitat para macroinvertebrados bentónicos recolectadas en el estado de Mississippi, USA. Los valores de " $n$ " representan el número de pares usados en el cálculo del CV.

an appropriate measure. Coefficient of variation (CV) should also be calculated by pooling values across all sample pairs. For Mississippi, the CV for the overall index was $10.6 \%$ (Fig. 1). Also, as noted in figure 1, the precision of repeat visits within crews and among crews was very similar, approximating the overall precision, indicating the multihabitat approach is equally precise regardless of which trained crew performs the sampling.

Another example on precision of field sampling is given by Verdonschot (1990). For each taxon the index of precision (IOP) was calculated to study the reproducibility of abundance. The index of precision is chosen to overcome the problem of differences in abundance of taxa (i.e., due to natural variation during a life cycle and/or variation caused by the sampling technique) when looking separately at standard deviation or arithmetic mean. The IOP is the ratio of standard error and arithmetic mean:

$$
\mathrm{IOP}=100 *(\text { standard error/arithmetic mean }) .
$$

The IOP provides the error percentage in the estimate of the population mean. An error percentage of zero implies that all samples are identical. Because absence obfuscates the outcome of the index, only the samples in which a taxon was 


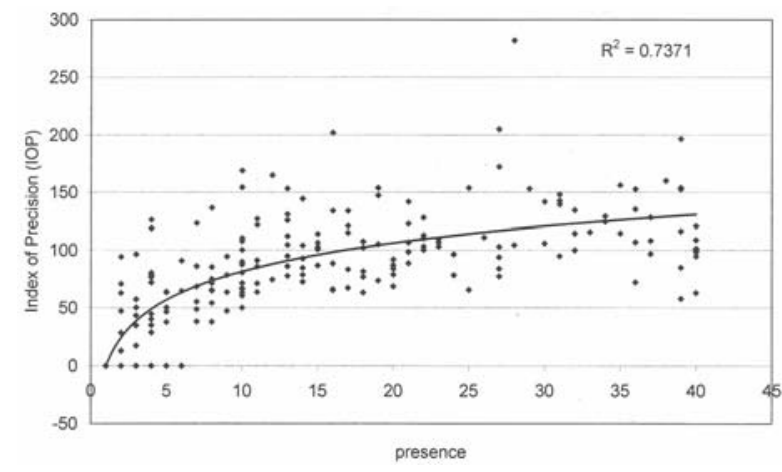

Figure 2. The relation between the presence of the taxa and the index of precision (IOP) calculated for observed abundances. Relación entre la presencia de taxones y el índice de precisión (IOP) calculado para las abundancias observadas.

present were taken into account. The precision of the value of the abundance of a taxon can only be indicated for the moment it was collected. For taxa collected only once, the standard deviation and the index are indeterminate.

In figures 2 and 3, the IOP of a taxon is plotted against its frequency. For observed abundances the index fluctuates between $60 \%$ and $200 \%$ (Fig. 2). This means that if a taxon is collected in one standard pond net sample, its abundance estimate is not very precise.

To make the distribution of observed values less skew, the abundances are transformed to a lo-

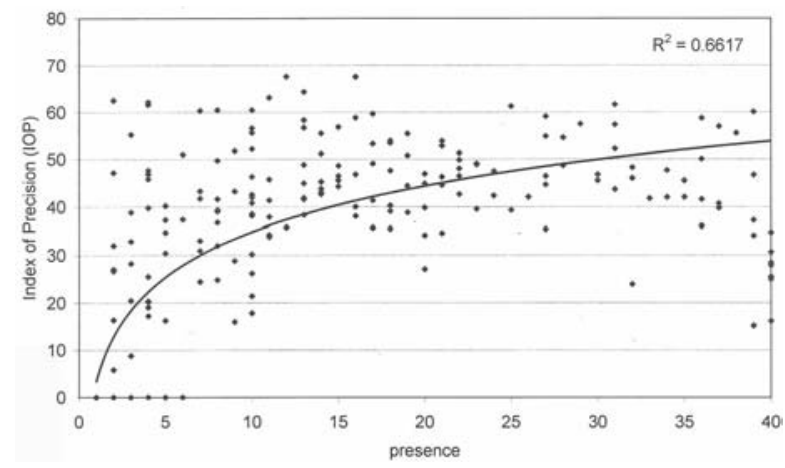

Figure 3. The relation between the presence of the taxa and the index of precision (IOP) calculated for transformed abundances. Relación entre la presencia de taxones y el indice de precisión (IOP) calculados para las abundancias transformadas. garithmic scale. The index for transformed abundances fluctuates around $45 \%$ (Fig. 3). Hence, this log transformation has been performed before processing the data. Elliott (1971) reported $20 \%$ (on the original scale) as a reasonable error in homogeneous bottom samples. The standard pond net samples were not taken from a homogeneous substratum but from several microhabitats. Therefore, an index error of $45 \%$ is considered acceptable when the conditions are more or less heterogeneous (patchy).

\section{Question 3-What is the relative ability of the multihabitat method to distinguish natural va- riability (i.e., temporal, spatial) from human disturbance?}

The ability of this method to distinguish natural variability from human disturbance is enhanced by minimizing method error and by calibrating relative to natural factors. Calibration of any biological assessment protocol entails stratification of the annual time period (index period to minimize seasonal influences) and areal extent (site class to incorporate biogeographic patterns and other natural factors) to which the index is applicable. Those sites exhibiting physical, chemical, and/or hydrologic stressor intensities of a predetermined level (or greater) make up the analytical truth (or true value). Sensitivity is very closely related to accuracy and is also reflected by discrimination efficiency (DE). The proportion of those sites correctly identified by the biological index as impaired is its accuracy, and is quantified as discrimination efficiency (DE). The multihabitat proportional method produced a mean DE of $89 \%$ in Maryland (across 2 bioregions) and $92 \%$ in Mississippi (across 5 bioregions) (Fig. 4). Maryland's Benthic Index of Biological Integrity (B-IBI) has a DE of $92 \%$ for non-coastal plain streams, and $88 \%$ for coastal plain streams (Stribling et al. 1998). The Mississippi Benthic Index of Stream Quality (M-BISQ) is stratified into 5 bioregions with DEs of $90 \%$ (Northwest, East, and West), $100 \%$ (Black Belt), and $89 \%$ (Northeast). 


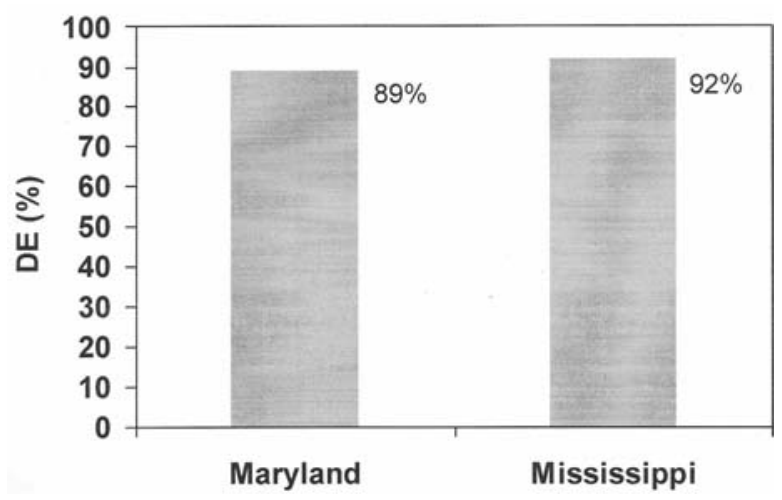

Figure 4. Discrimination efficiencies (DE) for benthic multimetric indexes calibrated for the USA states of Maryland and Mississippi. Eficiencias de discriminación (DE) para índices bentónicos multimétricos calibrados para los estados de Matyland y Mississippi de USA.

\section{Question 4-How would the multihabitat method be implemented for low-gradient streams?}

Development of a calibrated biological index, regardless of bioregion but specified for a stressor, has seven steps:

1. Identify candidate reference sites that represent the suite of habitat types in low gradient streams

2. To calibrate a biological index, sample along a gradient of sites from natural background to stressed sites with the selected stressor.

3. Compile and calculate candidate metrics that are ecologically relevant for low gradient streams.

4. Test candidate metrics for distinguishing between reference and impaired sites.

5. Aggregate metrics into biological index that is scientifically robust to measure the stressors.

6. Test validity of index using an independent dataset

Step 1 is the more effort-intensive component of this process. It includes selection of sites, sampling and processing of all field samples and data (biological, physical, and chemical), compilation of all ancillary data (e. g., land use), instituting appropriate and comprehensive quality assurance and quality control (QA/QC), and population of a flexible data management system. The number of stream sites necessary to adequately characterize each site class should be between 10-25, depending on landscape heterogeneity (higher number of sites for a more variable site class). Steps 2-6 are described in detail in Barbour et al., (1999).

\section{RECOMMENDATIONS}

The multihabitat approach to sampling for bioassessment has been well tested in the USA and in Europe. The approach is used in comprehensive surveys throughout broad jurisdictions. The primary advantage is to afford a versatile method for sampling a wide variety of stream types, and is applicable to evaluating both chemical and nonchemical stressors. Agencies and consortia interested in a multihabitat approach should (i) identify their program objectives that would be conducive to sampling representative aquatic habitats, (ii) characterize their aquatic systems such that the major stream types and associated habitats are described, (iii) agree upon a standard set of protocols for sampling the streams throughout the jurisdiction, and (iv) use only trained professionals to ensure a high level of precision and representativeness of the samples.

Legacy databases that have been populated with ecological data collected with other approaches should not be considered useless. The historical assessments conducted with these data are still valid as benchmarks, and cross-calibration analyses could be done to reconcile varying assessments. It is likely that after cross-calibraton, only a few differences in results will require substantiating a change in assessment of ecological condition.

\section{REFERENCES}

AQEM consortium. 2002. Manual for the application of the AQEM method. A comprehensive method to assess European streams using benthic macroinvertebrates, developed for the purpose of the Water Framework Directive. Version 1.0, February 2002. 89 pp. 
BARBOUR, M. T. 1997. The re-invention of biological assessment in the U.S. Human and Ecological Risk Assessment, 3: 933-940.

BARBOUR, M. T., J. GERRITSEN, B. D. SNYDER \& J. B. STRIBLING. 1999. Rapid Bioassessment Protocols for Use in Streams and Wadeable Rivers: Periphyton, Benthic Macroinvertebrates and Fish. Second Edition. EPA/841-B-99-002. U.S. EPA, Office of Water, Washington, D.C. 197 pp. plus appendices.

BARBOUR, M. T., J. GERRITSEN, G. E. GRIFFITH, R. FRYDENBORG, E. MCCARRON, J. S. WHITE \& M. L. BASTIAN. 1996. A framework for biological criteria for Florida streams using benthic macroinvertebrates. J. North Am. Benthol. Soc., 15: 185-211.

DAVIS, W. S. \& T. P. Simon (eds.).1995. Biological assessment and criteria: Tools for water resource planning and decision making. Lewis Publishers, Boca Raton, Florida. 415 pp.

DE LANGE, L. \& M. A. DE RUITER.1977. Biologische Waterbeoordeling. Methoden voor het beoordelen van Nederlands oppervlaktewater op biologische grondslag. Werkgroep Biologische Waterbeoordeling. Instituut voor Milieuhygiëne en Gezondheidstechniek TNO, Delft. 251 pp.

ELLIOTT, J. M. \& P.A. TULLETT. 1983. A bibliography of samplers for benthic invertebrates. Freshwater Biological Association, Occasional Publication, 20. 1-26.

ELLIOTT, J. M. 1971. Some methods for the statistical analysis of samples of benthic invertebrates. Freshwat. Biol. Ass. Sc. Publ., 25. 248 pp.

ENVIRONMENT AGENCY. 1999. Procedures for collecting and analysing macroinvertebrate samples. Environment Agency Document BT001. 179 pp.

FLORIDA DEPARTMENT OF ENVIRONMENTAL PROTECTION (FL DEP). 1996. Standard operating procedures for biological assessment. Florida Department of Environmental Protection, Biology Section. July 1996. 98 pp.

FURSE M. T., J. F. WRIGHT, P. D. ARMITAGE \& D. MOSS. 1981. An appraisal of pond-net samples for biological monitoring of lotic macroinvertebrates. Wat. Res., 15: 679-689.

HERING, D., O. MOOG, L. SANDIN \& P. F. M. VERDONSCHOT. 2004. Overview and application of the AQEM assessment system. Hydrobiologia, 516: 1-20.

ISO 7828. 1985. Water quality -methods of biological sampling- guidance on handnet sampling of aquatic benthic macro-invertebrates. Ref. No. ISO 7828-1985 (E). 6 pp.

LENAT, D. R. 1988. Water quality assessment of streams using a qualitative collection method for benthic macroinvertebrates. J. North Am. Benthol. Soc., 7: 222-233.

LENAT, D. R. 1990. Reducing variability in freshwater macroinvertebrate data. In: Proceedings of the 1990 Midwest Pollution Control Biologists Meeting. W. S. Davis (ed.).:1 9-32. U.S. EPA Region V, Environmental Sciences Division, Chicago, IL. EPA-905-9-90/005.

LENAT, D. R. \& M. T. BARBOUR. 1994. Using benthic macroinvertebrate community structure for rapid, cost-efficient, water quality monitoring: Rapid bioassessment. In: Biological Monitoring of Aquatic Systems. S. L. Loeb and A. Spacie (eds).: 187-215. Lewis Publishers, Ann Arbor, Michigan.

LOEB, S. L. \& A. SPACIE. 1994. Biological Monitoring of Aquatic Systems. Lewis Publications, Boca Raton, Florida. 381 pp.

MAJOR, E. B. \& M. T. BARBOUR. 2001. Standard operating procedures for the Alaska Stream Condition Index: A modification of the U.S. EPA Rapid Bioassessment Protocols. $5^{\text {th }}$ ed. Prepared for the Alaska Department of Environmental Conservation. Environment and Natural Resources Institute, University of Alaska Anchorage, Anchorage, AK. 1 vol. 52 pp.

MAJOR, E. B., M. T. BARBOUR, J. S. WHITE \& L. S. HOUSTON. 1998. Development of a biological assessment approach for Alaska streams: A pilot study on the Kenai Peninsula. Environment and Natural Resources Institute, University of Alaska Anchorage, Anchorage, AK. Report for Alaska Department of Environmental Conservation, Anchorage, AK. 31 pp. and appendix. 68 pp.

MASSACHUSETTS DEPARTMENT OF ENVIRONMENTAL PROTECTION (MA DEP). 1995. Massachusetts DEP preliminary biological monitoring and assessment protocols for wadable rivers and streams. Massachusetts Department of Environmental Protection, North Grafton, Massachusetts. $121 \mathrm{pp}$.

MAXTED, J. R., M. T. BARBOUR, J. GERRITSEN, V. PORETTI, N. PRIMROSE, A. SILVIA, D. PENROSE \& R. RENFROW. 2000. Assessment framework for mid-Atlantic coastal plain streams using benthic macroinvertebrates. J. North Am. Benthol. Soc., 19: 128-144. 
MID-ATLANTIC COASTAL STREAMS WORKGROUP (MACS). 1996. Standard operating procedures and technical basis: Macroinvertebrate collection and habitat assessment for low-gradient nontidal streams. Delaware Department of Natural Resources and Environmental Conservation, Dover, Delaware. 136 pp.

MINSHALL, G. W. 1984. Aquatic insect-substratum relationships. In: The ecology of aquatic insects. V.H. Resh and D.M. Rosenberg (eds.): 358-400. Praeger Publishers, New York.

MISSISSIPPI DEPARTMENT OF ENVIRONMENTAL QUALITY (MDEQ). 2003. Development and Application of the Mississippi Benthic Index of Stream Quality (MBISQ). June 30, 2003. Mississippi Department of Environmental Quality, Office of Pollution Control, Jackson, MS. 82 pp. plus appendices.

MOOG, O., A. CHOVANEC, J. HINTEREGGER \& A. RÖMER. 1999. Richtlinie zur Bestimmung der saprobiologischen Gewässergüte von Fließgewässern. Bundesministerium für Land-und Forstwirtschaft, Wien. 144 pp.

PLAFKIN, J. L., M. T. BARBOUR, K. D. PORTER, S. K. GROSS \& R. M. HUGHES. 1989. Rapid bioassessment protocols for use in streams and rivers: Benthic macroinvertebrates and fish. EPA/440/489/001. U.S. EPA Office of Water, Washington, DC. 128 pp. pluis appendices.
ROSENBERG, D. M. \& V. H. RESH. 1993. Introduction to freshwater biomonitoring and benthic macroinvertebrates. In: Freshwater biomonitoring and benthic macroinvertebrates. D. M. Rosenberg and V. H. Resh (eds.): 1-8. Chapman and Hall, New York.

SLÁDECEK, V. 1973. System of water quality from the biological point of view. Ergebnisse der Limnologie, 7: 1-128.

STRIBLING, J. B., B. K. JESSUP, J. S. WHITE, D. BOWARD \& M. HURD. 1998. Development of a Benthic Index of Biotic Integrity for Maryland Streams. Maryland Department of Natural Resources. MANTA Report No. CBWP-EA-98-3. Annapolis, MD. $36 \mathrm{pp}$.

VERDONSCHOT, P. F. M. 1990. Ecological characterization of surface waters in the province of Overijssel (The Netherlands). Thesis, Wageningen, 255 pp.

WOODIWISS, F. S. 1978. Comparative study of biological-ecological water quality assessment methods. Summary report, Commission of the European Communities. Nottingham, Sept/Oct. 1976. $231 \mathrm{pp}$.

WRIGHT, J. F., D. W. SUTCLIFFE \& M. T. FURSE (eds.). 2000. Assessing the biological quality of fresh waters - RIVPACS and other techniques. Freshwater Biological Association, Ambleside, Cumbria, UK, 373 pp. 
